\title{
ENDOTOXIN PRODUCTION FROM ESCHERICHIA COLI \\ O157 LOCALLY ISOLATED FROM SOME EGYPTIAN \\ FOODS AND ITS EFFECT ON LIVER EFFICIENCY IN \\ RATS
}

\author{
Hussein, Hanaa ${ }^{(1)}$; $_{\text {Barakat, Heba }}{ }^{(2)}$; Roushdy M. M. ${ }^{(3)}$ \\ and Shoukry, Nashwa
}

1) Nutritional Chemistry and Metabolism Department, National Nutrition Institute 2) Biochemistry and Nutrition Department, Women's College for Arts, Science and Education, Ain Shams University 3) Botany and Microbiology Department, Faculty of Science, Al-Azhar University

\begin{abstract}
This study was conducted to investigate the possibility of food poisoning bacteria isolated from local Egyptian markets. A total of 100 samples made up of five types of Egyptian food staff were isolated from different food sources [smoked beef salami, Ringa (smoked herring), Fesikh (un-gutted salted fish), Luncheon and Basturma (cured beef)] collected from different Egyptian local markets. The isolated bacteria species after biochemical and serological typing were Escherichia coli O157.The effects of bacterial endotoxin extracted from bacterial isolate on liver enzyme changes were investigated. Little information is available about the direct effect of bacterial endotoxin on the onset of liver impairment. In this work, 32 Sprague Dawley rats (males) were injected intraperitoneally with endotoxin derived from $E$. coli culture supernatant to induce impairment of liver functions. Study detected an obvious increase in ALT as well as AST values and reduction it with treated by oils as antioxidant. Study suggests that these alterations in liver functions could be related to the development of liver damage in response to significant dose of bacterial endotoxin.

Keywords:Endotoxin Production, Escherichia coli O157, Egyptian foods, Liver Efficiency, Sprague Dawley Rats
\end{abstract}


J. Environ. Sci.

Institute of Environmental Studies and Research - Ain Shams University

\section{INTRODUCTION}

In Egypt, a very limited research work was done concerning epidemiological studies of food poisoning as an important vehicle associated with illnesses caused by food borne pathogens, which lead to the development of public health hazards (Hakim et al., 2015).

The related proteins Shiga-like toxin 1 (STX1) and Shiga-like toxin 2 (STX2) are produced by various pathogenic strains of Shiga toxin-producing Escherichia coli (STEC) responsible for food-borne illnesses globally (Hall et al., 2017). Commonly, the developing countries (Egypt is an example) have bad raw food hygiene, lack incidence of food borne disease and antimicrobial resistance epidemiology. Thus, management of biological hazards transmitted to humans by food consumption is of major health significance (Thi Thu $e t$ al., 2007).

Human food-borne illness associated with Shiga toxin-producing $E$. coli (STEC) is mainly due to consumption of foods that have been contaminated with feces. STEC and Shigella dysenteriae type I produce potent cytotoxins known as Shiga toxins (Stxs) and can cause kidney complications in susceptible individuals (Bergan et al., 2012). Several epidemiological studies have linked human listeriosis to specific foods, such as soft cheeses, melons or undercooked meat (Varma et al., 2007). The clinical manifestations include but are not limited to gastroenteritis, meningitis and spontaneous miscarriage (CDC, 2011). 
Many researchers have examined the in vitro and in vivo effects of fatty acids on bacterial toxins, including their ability to survive, grow, and colonize in cattle, as well as the effects of fatty acids on host immune responses to these toxins (Harrison et al., 2013). Another study demonstrated that combining plant metabolites and the short chain fatty acids inhibited E. coli O157 growth more than the individual components, suggesting that appropriate nutrition could help reduce the numbers of pathogenic E. coli in food animals prior to slaughter (Nakanishi et al., 2009). They also found that high concentrations of a mixture of acetate, propionate, and butyrate inhibited growth of the O157:H7 in vitro, however, low concentrations enhanced the expression of virulence genes involved in adherence and pathogenesis.

In addition, Poly-Unsaturated Fatty Acids (PUFAs) as Omega-3 and Omega-6 have also been examined for their ability to affect host response to STEC as well as E. coli growth. In the renal epithelial tubule cell line, PUFAs appeared to decrease cell death caused by Stxs (Sasaki and Takita, 2006).

The present study was undertaken to provide a baseline data for strains isolated from local and imported food products in Egyptian markets and doing a trial to reduce the toxicity of these strains either by eating a healthy food or by administration of medication of natural origin.

\section{MATERIALS AND METHODS}

Sample collection: One hundred samples were isolated from different food sources [smoked beef salami, Ringa (smoked herring), Fesikh (un-gutted salted fish), Luncheon and Basturma (cured beef)] collected from different Egyptian local markets. An obvious color change (brownish to greenish) of 
the collected food was the target for the isolation of bacteria. These predicted sites (as a source of infection) were transferred carefully to sterile nutrient agar plates under sterilized conditions and allowed to grow for $24 \mathrm{~h}$ at $37^{\circ} \mathrm{C}$. After growth, the growing colonies were subjected to further purification and identification.

Isolation and identification of $\boldsymbol{E}$. coli isolates: Each of the food samples was homogenized in a sterile mortar and $1 \mathrm{~g}$ of the homogenate food sample was suspended in $9 \mathrm{ml}$ buffered peptone water. Serial dilutions of up to $10^{-7}$ were then made and $1 \mathrm{ml}$ of each was plated on Eosin methylene blue (EMB) agar, MacConkey (MAC) agar and blood agar (BA) media. They were then incubated at $37^{\circ} \mathrm{C}$ for $24 \mathrm{~h}$. Pure cultures of all colonies exhibited typical dark to purple red colonies with metallic sheen, red to pink colonies as well as $\beta$ hemolytic colonies which are characteristic of E. coli on EMB, MAC and BA respectively. Motility test was also done using 2,3,5-triphenyltetrazolium chloride (TTC)motility agar media. The selected colonies were then made in readiness for biochemical tests. Identification using Biochemical tests to confirm E. coli was done using the API 20E test strips and in accordance with the method described by Holt et al. (1994).

Endotoxin production: Cell suspensions $(2 \mathrm{ml})$ of buffered peptone water were placed in pyrogen-free tubes for measurement of endotoxin using the Limulus amoebocyte lysate (LAL) assay. Escherichia coli lipopolysaccharide (purchased from Sigma, USA) was used as an endotoxin standard control. Test samples were incubated for $1 \mathrm{~h}$ in a water bath at $37^{\circ} \mathrm{C}$; a test result was considered positive only if the resulting clot remained firm after $180^{\circ}$ 
inversion. Sterile bottles of buffered peptone water were run as negative controls (Holt et al. 1994).

Biological experiment: Male Sprague-Dawley rats that weighted 150-200g were used. Animals were first left for 7days to acclimatize to laboratory conditions. They were maintained at $25 \pm 1^{\circ} \mathrm{C}$. Animals were randomly allocated to control and treatment groups (8rats/group) as follow:

- Group 1: Was fed on normal diet (as control).

- Group 2: Was fed on normal diet to be injected with the bacterial toxin (as positive control).

- Group 3: Was fed on normal diet supplemented with flaxseed oil.

- Group 3: Was fed on normal diet supplemented with fish oil.

After 30 days of feeding, all groups were intraperitoneally injected by the bacterial toxin except the control. After $24 \mathrm{~h}$ of injection, blood samples were withdrawn from hepatic portal vein and collected in glass tubes. Serum was obtained by centrifugation of blood at 4000rpm. Values of aspartate aminotransferase (AST); alanine aminotransferase (ALT) and alkaline phosphatase (ALP) were determined by using Hitachi 911 (automated instrument, Japan).

\section{RESULTS AND DISCUSSIONS}

Bacteria are one of the most common causes of food poisoning. Unlike food spoilage bacteria, food poisoning bacteria do not affect the taste, smell or look of food. Food poisoning bacteria may cause problems in one of four main ways. They may transfer from raw to ready-to-eat foods due to poor handling and storage practices or may transfer onto foods from food handlers, 
pests or dirty equipment and utensils or may survive in food that is undercooked or may grow in food that is not stored at the correct temperature. E. coli, which are normal flora of the human and animal intestine, have been identified as a leading cause of food borne illness all over the world (Pie'rard et al., 2012). E. coli and the E. coli 0157 strains have previously been isolated from meat samples (Hussein, 2007). E. coli 0157 strain was detected in some of samples screened in this study. One hundred samples were collected (Table 1) and tested for their microbial content. The samples were classified as follow: Basturma (18\%), Fesikh (21\%), Luncheon (31\%), Salami (10\%) and Ringa (20\%). E. coli 0157 was suggested to be contained in Luncheon (8 isolates) and Ringa samples (12 isolates) according to their morphological, staining and motility characters (Gram negative, short rods and motile).

This result is consistent with the work of Guh et al. (2010), whose study showed high prevalence rate of $E$. coli in uncooked meat samples. The result is also in agreement with the work of Hussein (2007), who recorded E. coli 0157: $\mathrm{H} 7$ prevalence rates in the range of 3 to $19.7 \%$ for beef cattle. These results are indication of the poor sanitary environment under which the animals are slaughtered and sold. Guh et al. (2010) reported that meat is frequently found to be contaminated due to poor sanitary environment during slaughter, transportation and usage and through handling. 
Table 1: Isolation and preliminary identification of the isolated bacteria

\begin{tabular}{|c|c|c|c|c|}
\hline Source & $\begin{array}{c}\text { No. of isolates } \\
(\mathbf{1 0 0} \text { isolates })\end{array}$ & $\begin{array}{c}\text { Gram } \\
\text { Reaction }\end{array}$ & $\begin{array}{c}\text { Microscopic } \\
\text { examination }\end{array}$ & Motility \\
\hline \hline \multirow{2}{*}{$\begin{array}{c}\text { Basturma } \\
(18 \%)\end{array}$} & 4 & Positive & Cooci & Non-motile \\
\cline { 2 - 5 } & 14 & Positive & Bacilli & motile \\
\hline \multirow{2}{*}{$\begin{array}{c}\text { Fesikh } \\
(21 \%)\end{array}$} & 3 & Positive & Cooci & Non-motile \\
\cline { 2 - 5 } & 9 & Positive & Bacilli & motile \\
\hline \multirow{3}{*}{$\begin{array}{c}\text { Luncheon } \\
(31 \%)\end{array}$} & 3 & Negative & Bacilli & Non-motile \\
\cline { 2 - 5 } & 7 & Positive & Cooci & Non-motile \\
\cline { 2 - 5 } & 13 & Positive & Bacilli & motile \\
\hline Salami(10\%) & 10 & Negative & Short rods & motile \\
\hline \multirow{2}{*}{$\begin{array}{c}\text { Ringa } \\
(20)\end{array}$} & 5 & Positive & Bacilli & Non-motile \\
\cline { 2 - 5 } & 12 & Positive & Bacilli & motile \\
\cline { 2 - 5 } & 3 & Negative & Short rods & motile \\
\hline \hline
\end{tabular}

In a trial to identify the most likely isolates that may be suggested as $E$. coli 0157,20 isolates (8 Isolates form Luncheon and 12 Isolates from Ringa) were tested to grow on EMB, MAC and BA.

The results showed in Table 2 recorded that, only 2 isolates were suggested to be E. coli 0157 [one form Luncheon (52L) and one from Ringa (44R)].

Table 2: Second step in the identification of the isolated bacteria

\begin{tabular}{|c|c|c|c|c|c|}
\hline Source & \multirow{2}{*}{$\begin{array}{c}\text { Isolates } \\
(\text { Total }=20)\end{array}$} & \multicolumn{3}{|c|}{ Isolate characteristics } & \multirow{2}{*}{$\begin{array}{l}\text { Isolate } \\
\text { symbol }\end{array}$} \\
\hline \multirow{4}{*}{$\begin{array}{c}\text { Ringa } \\
\text { (12 Isolates) }\end{array}$} & & MAC & EMB & BA & \\
\hline & 4 & $\overline{\mathrm{LF}}$ & None & NHL & ---- \\
\hline & 1 & $\overline{L F}$ & GMS & $\mathrm{HL}$ & $44 R$ \\
\hline & 7 & NLF & None & NHL & --- \\
\hline \multirow{3}{*}{$\begin{array}{l}\text { Luncheon } \\
\text { (8 Isolates) }\end{array}$} & 2 & LF & None & NHL & ---- \\
\hline & 1 & $\mathrm{LF}$ & GMS & $\mathrm{HL}$ & $52 \mathrm{~L}$ \\
\hline & 5 & NLF & None & NHL & ---- \\
\hline
\end{tabular}

*LF= Lactose Fermenter

$* \mathrm{NLF}=$ Non-Lactose Fermenter

$* \mathrm{GMS}=$ Green metallic sheen $* \mathrm{HL}=$ Haemolytic $\quad * \mathrm{NHL}=$ Non haemolytic 
E. coli is a normal inhabitant of the gut and has been isolated on several occasions from animal and human faeces (Sayah et al., 2005). Another likely source of contamination with this organism is the vehicles on which the meat or fishes are transported to the various sales point. Most significant of this study is the fact that E. coli was isolated from "ready to eat" food. This result is even higher than that recorded for open market fresh meat which will still be processed before consumption.

Confirmation tests for E. coli were applied using API 20 E kit system which is a biochemical panel for identification and differentiation of members of the family Enterobacteriaceae. The plastic strip holds twenty mini-test chambers containing dehydrated media having chemically-defined compositions for each test. These include: ONPG: Test for $\beta$-galactosidase enzyme, ADH: Test for decarboxylation of amino acid arginine by arginine decarboxylase, LDC: Test for decarboxylation of amino acid lysine by lysine decarboxylase, ODC: Test for decarboxylation of amino acid ornithine by ornithine decarboxylase, CIT: Utilization of citrate as sole carbon source, $\mathrm{H}_{2} \mathrm{~S}$ : Production of hydrogen sulphide, URE: Test for urease enzyme, TDA: Detection of tryptophan deaminase enzyme, IND: Production of indole from tryptophan after addition of Kovac's reagent, VP: Voges-Proskauer test for the detection of acetoin, GEL: Test for production of gelatinase enzyme, GLU: Fermentation of glucose, MAN: Fermentation of mannose, INO: Fermentation of inositol, SOR: Fermentation of sorbitol, RHA: Fermentation of rhamnose, SAC: Fermentation of sucrose, MEL: Fermentation of melibiose, AMY: Fermentation of amygdalin and ARA: Fermentation of 
arabinose. These tests are inoculated with a bacterial suspension that reconstitutes the media. During incubation, metabolism produces color changes that are either spontaneous or revealed by the addition of reagents (Table 3).

Table 3: Identification of the isolates using API 20E test

\begin{tabular}{|c|c|c|c|}
\hline Serial No. & Biochemical tests & 44R Isolate & 52L Isolate \\
\hline 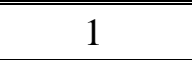 & 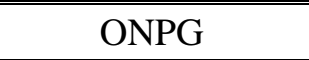 & + & + \\
\hline 2 & $\mathrm{ADH}$ & - & - \\
\hline 3 & LDC & + & + \\
\hline 4 & ODC & + & + \\
\hline 5 & CIT & - & - \\
\hline 6 & $\mathrm{H}_{2} \mathrm{~S}$ & + & + \\
\hline 7 & URE & - & - \\
\hline 8 & TDA & - & - \\
\hline 9 & IND & + & + \\
\hline 10 & $\mathrm{VP}$ & - & - \\
\hline 11 & GEL & - & - \\
\hline 12 & GLU & + & + \\
\hline 13 & MAN & + & + \\
\hline 14 & INO & - & - \\
\hline 15 & SOR & - & - \\
\hline 16 & RHA & - & - \\
\hline 17 & SAC & + & + \\
\hline 18 & MEL & + & + \\
\hline 19 & AMY & - & - \\
\hline 20 & ARA & + & + \\
\hline
\end{tabular}

$(+)=$ Positive $(-)=$ Negative 
The results recorded in Table 4 have shown that bacterial endotoxin at low doses is capable of producing alterations in liver functions. These alterations have significant differences between positive control group and other groups. These results may be appeared in the liver probably because this organism mainly responsible for detoxification of foreign compounds in the body. These phenomena agreed with the investigation of Diniz et al. (2004) who found elevation of the levels of hepatic enzymes in the plasma of the consuming population toxin from a bloom of the blue-green alga with water. Fish and flaxseed oil supplementation significantly reduced levels of hepatic enzymes. This reduction may happen because the two oils contain omega 3 as antioxidant create prevention effect. These results are in accordance of Moreira et al. (2013) who demonstrated that the nutritional recovery of animals was enabled by different concentrations of Spirulina which contains many nutritional values as well as different vitamin content.

Table 4: Liver function tests of control versus treated rats

\begin{tabular}{|l|l|l|l|l|}
\hline \multicolumn{1}{|c|}{ Parameters } & \multicolumn{1}{|c|}{$\begin{array}{c}\text { G1 } \\
\text { Normal } \\
\text { control }\end{array}$} & \multicolumn{1}{|c|}{$\begin{array}{c}\text { G2 } \\
\text { positive } \\
\text { control }\end{array}$} & $\begin{array}{c}\text { G3 } \\
\text { Treated } \\
\text { with fish oil }\end{array}$ & $\begin{array}{c}\text { G4 } \\
\text { Treated with } \\
\text { Flaxseed oil }\end{array}$ \\
\hline GPT (U/L) & $46.8 \pm 1.8^{\mathrm{a}}$ & $54.3 \pm 2.7^{\mathrm{b}}$ & $39.8 \pm 1.5^{\mathrm{c}}$ & $43.7 \pm 2.1^{\text {ac }}$ \\
\hline GOT (U/L) & $99.8 \pm 2.7^{\mathrm{a}}$ & $153.9 \pm 3.4^{\mathrm{b}}$ & $91.1 \pm 1.7^{\mathrm{c}}$ & $109.6 \pm 3.1^{\mathrm{d}}$ \\
\hline ALP(U/L) & $79.9 \pm 1.9^{\mathrm{a}}$ & $147.7 \pm 1.3^{\mathrm{b}}$ & $64.0 \pm 1.9^{\mathrm{c}}$ & $78.1 \pm 3.7^{\mathrm{a}}$ \\
\hline
\end{tabular}

Values are expressed as means $\pm \mathrm{SD}, \mathrm{n}=8$

Means in the same row with different letters are significantly different. *Significant $(\mathrm{p} \leq 0.05)$. 


\section{CONCLUSION}

In conclusion, the results of the present investigation revealed that bacterial endotoxin even at low doses are capable of producing obvious changes in the liver functions. Clinical chemistry data showed elevations of ALT and AST. Conclusively it is to be noted that with the low level of sanitary practices observed and lack of adequate data on infections outbreak in Egypt E. coli 0157 could spread easily without early detection and as such it is important to take seriously the isolation of the organism in food materials from this study. Consequent upon this, it is recommended that consumers cook their meat properly before they are consumed and also avoid indiscriminate eating of meat sold in the open that is not properly reheated.

\section{REFERENCES}

Bergan J., DyveLingelem A. B., Simm, R., Skotland T., Sandvig K. (2012): Shiga toxins. Toxicon, 60, 1085-1107.

Centers for Disease Control and Prevention (CDC) (2011). Prevention, multistate outbreak of listeriosis associated with Jensen Farms cantaloupe United States, August-September 2011. MMWR Morb.Mortal. Wkly. Rep., 60, 1357-1358.

Diniz Y. S., Fernando A. A., Campos K. E., Ribas B. D., Novelli E. L. 2004 Toxicity of Hyper Caloric Diet and Monosodium Glutamate: Oxidative Stress and Metabolic Shifting in Hepatic Tissue. Food and Chemical Toxicology, Vol. 42, pp. 319-325.

Guh, A., Phan, Q., Nelson, R., Purviance, K., Milardo, E., Kinney, S., Mshar, P., Kasacek, W. \&Cartter, M. (2010). Outbreak of Escherichia coli O157 associated with raw milk, Connecticut, 2008. Clin Infect Dis 51, 1411-1417. 
Hakim A. S., Abuelnaga1 A. S. M., Ezz-EldeenA. M., Bakry M. A., Ismail S. A. (2015): Prevalence of some food poisoning bacteria in local and imported retail pork by-products in Egyptian markets. Afr. J. Microbiol. Res.9 (22), 1492-1498.

Hall G., Kurosawa S., Stearns-Kurosawa D. J. (2017): Shiga Toxin Therapeutics: Beyond Neutralization. Toxins, 9, 291

Harrison L. M., Balan K. V., Babu U. S. (2013): Dietary Fatty Acids and Immune Response to Food-Borne Bacterial Infections. Nutrients, $5,1801-1822$

Holt J. G., Krieg N. R., Sneath, P. H. A., Stately J. T., Williams S. T. (1994). Bergey's Manual of Systematic Bacteriology, 9th Ed, Williams and Wilkins Company, Baltimore, USA, pp. 787-800.

Hussein H. S. (2007): Prevalence and Pathogenicity of Shiga toxin producing Escherichia coli in beef cattle and their products. J. Anim. Sci. 85: E63-E72.

Moreira L. M., Behling B. S., Rodrigues R. S., Costa J. A. V., S. Soares L. A. (2013). Spirulina as a Protein Source in the Nutritional Recovery of Wistar Rats. Braz. Arch. Biol. Technol. 56 (3): 447-456

Nakanishi, N.; Tashiro, K.; Kuhara, S.; Hayashi, T.; Sugimoto, N.; Tobe, T. (2009): Regulation of virulence by butyrate sensing in enterohaemorrhagic Escherichia coli. Microbiology, 155, 521530.

Pie'rard, D., De Greve, H., Haesebrouck, F. \& Mainil, J. (2012). O157:H7 and O104:H4 Vero/Shiga toxin-producing Escherichia coli outbreaks: respective role of cattle and humans. Vet Res 43, 13.

Sasaki, T.K.; Takita, T. (2006): Contribution of polyunsaturated fatty acids to Shiga toxin cytotoxicity in human renal tubular epitheliumderived cells. Biochem.Cell. Biol., 84, 157-166.

Sayah R. S., Kaneene J. B., Johnson Y., Miller R. (2005): Patterns of antimicrobial resistance observed in Escherichia coli isolates from domestic and wild animal fecal samples, human septage and surface water. Appl. Environ. Microbiol., 71: 1394-1404. 
Thi Thu H. V., George M., Taghrid I., Linh T. T., Peter J. C. (2007): Detection of Salmonella spp. in retail raw food samples from Vietnam and characterization of their antibiotic resistance. Appl. Environ. Microbiol. 73(21): 6885-6890.

Varma, J.K.; Samuel, M.C.; Marcus, R.; Hoekstra, R.M.; Medus, C.; Segler, S.; Anderson, B.J.; Jones, T.F.; Shiferaw, B.; Haubert, N. (2007): Listeria monocytogenes infection from foods prepared in a commercial establishment: A case-control study of potential sources of sporadic illness in the United States. Clin. Infect. Dis., $44,521-528$.

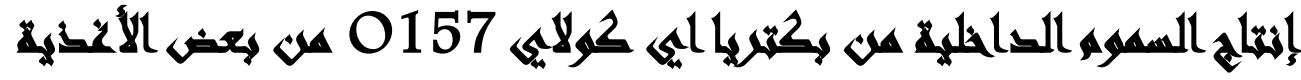

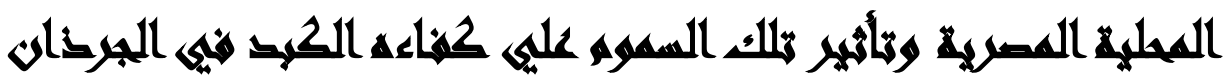

\section{[r]}

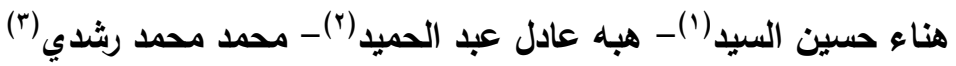
نشوة شكري محمود شاهين

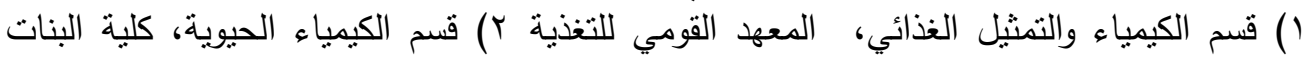

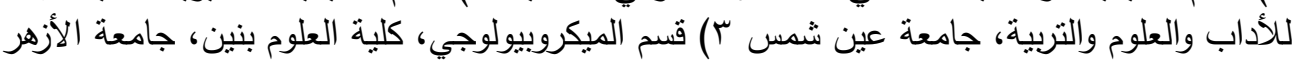

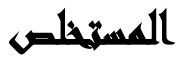

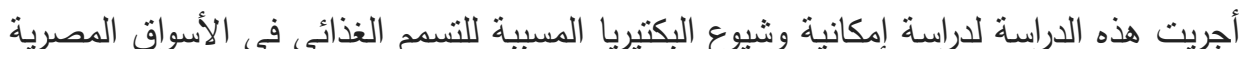

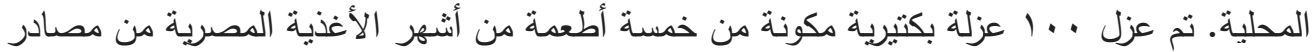
مختلفة. - ت تم جمع سلامه، لحم البقر المدخن، رنجة (رنجة مدخنة)، فسيخ (أسماك مملحة)، و بسطرمة (لحم بقر ) من مختلف الأسواق المحلية المصرية. - كانت أهم أنواع البكتيريا المعزولة بعد التعريف باستخدام الطرق البيوكيميائية والمصلية هي بكتيريا

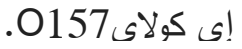
تم دراسة نأثير مستخلص السموم البكتيرية الداخلية المستخرج من العزلة البكتيرية على انزيمات

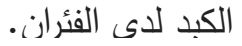
- تم حقن ؟ ك فأر من سلالة سبراغ داولي (ذكور) لمستخلص السموم البكتيرية الداخلية المستخرج من العزلة البكتيرية. 
J. Environ. Sci.

Institute of Environmental Studies and Research - Ain Shams University

$$
\text { - تم اكتشاف زيادة واضحة في إنزيمات الكبد لدي الفئران. }
$$

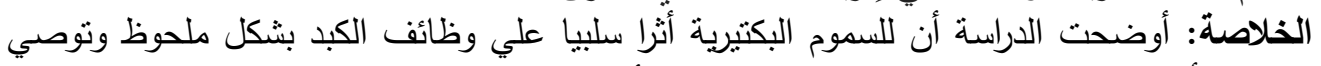

الدراسة بأن تتاول الغذاء الصحي قد يقلل من تلك الأثار . 